\title{
ArcheoSciences
}

Revue d'archéométrie

\section{Archaeobotanic: HPLC molecular profiles for the discrimination of copals in Mesoamerica. Application to the study of resin materials from objects of Aztec offerings}

Archeobotanique : profils moléculaires par CLHP pour la discrimination des copals en méso-Amérique. Application à l'étude de matières resineuses provenant d'offrandes aztèques

Paola Lucero-Gómez, Carole Mathe, Cathy Vieillescazes, Lauro BucioGalindo, Irma Belio-Reyes and Rito Vega-Aviña

\section{(2) OpenEdition}

\section{Journals}

Electronic version

URL: https://journals.openedition.org/archeosciences/4204

DOI: 10.4000/archeosciences.4204

ISBN: 978-2-7535-3691-3

ISSN: $2104-3728$

Publisher

Presses universitaires de Rennes

\section{Printed version}

Date of publication: 30 November 2014

Number of pages: 119-133

ISBN: 978-2-7535-3689-0

ISSN: 1960-1360

\section{Electronic reference}

Paola Lucero-Gómez, Carole Mathe, Cathy Vieillescazes, Lauro Bucio-Galindo, Irma Belio-Reyes and Rito Vega-Aviña, "Archaeobotanic: HPLC molecular profiles for the discrimination of copals in Mesoamerica. Application to the study of resin materials from objects of Aztec offerings", ArcheoSciences [Online], 38 | 2014, Online since 30 November 2016, connection on 28 January 2022. URL: http://journals.openedition.org/archeosciences/4204 ; DOI: https://doi.org/10.4000/ archeosciences.4204 


\title{
Archaeobotanic: HPLC Molecular Profiles for the Discrimination of Copals in Mesoamerica Application to the Study of Resin MLaterials from Objects of Aztec Offerings
}

\author{
Archéobotanique : profils moléculaires par CLHP \\ pour la discrimination des copals en méso-amérique \\ Application à l'étude de matières resineuses provenant d'offrandes aztèques
}

\author{
Paola Lucero-Gómez ${ }^{a}$, Carole Mathe ${ }^{a}$, Cathy Vieillescazes ${ }^{a}$, \\ Lauro Bucio-Galindo ${ }^{b}$, Irma Belio-Reyes ${ }^{c}$ et Rito Vega-Aviña ${ }^{d}$
}

\begin{abstract}
During archaeological excavations at «Templo Mayor» site, between 2006 and 2008 in Mexico City, thirteen Aztec offerings were found. Among the materials of these offerings the most abundant was a resinous substance used as adhesive, molding material for figures or as a spiritual offering. Two archaeological samples from two Aztec artifacts were analyzed by HPLC. Their global molecular profile was compared to that of fresh botanically certified copal resins from six species of Mexican Bursera (Burseraceae family). This study aims to complete a previous research based on GC-MS results that focused only on triterpenic molecular resin composition. The molecular profile of archaeological samples suggests a botanical copal origin related to B. bipinnata or maybe B. stenophylla species which triterpenic profile composition is identical to.
\end{abstract}

Résumé : Lors des fouilles archéologiques menées sur le site du "Templo Mayor " entre 2006 et 2008 à Mexico, treize offrandes Aztèques ont été retrouvées. Parmi les objets issus de ces offrandes, le matériau le plus abondant était de type résine sous forme d'adhésif, de matériel de moulage pour des figurines ou encore comme offrande spirituelle. Parmi ces derniers, deux échantillons archéologiques ont été analysés par CLHP. Leur profil moléculaire global a été comparé à celui de résines contemporaines d'origine botanique certifiée provenant de six espèces mexicaines de copal: Bursera (famille des Burséracées). Cette étude vient compléter et confirmer les résultats d'une recherche antérieure menée par CPG-SM où seule la fraction triterpénique des résines avait été étudiée. Le profil moléculaire de ces échantillons Aztèques suggère des copals dont l'origine botanique est l'espèce B. stenophylla ou bien B. bipinnata dont le profil moléculaire triterpénique est identique.

Keywords: archaeobotanic, Aztec, Bursera, copal, plant resin, triterpenoids.

Mots clés : archéobotanique, Aztèque, Bursera, copal, résine végétale, triterpènes.

\footnotetext{
a University of Avignon, IMBE UMR7263/ IRD237, Avignon University/ CNRS/ IRD/AMU, Restoration Engineering of Natural and Cultural Heritage. Address: 33 rue Louis Pasteur, F-84000, Avignon, France. (carole.mathe@univ-avignon.fr)

${ }^{\mathrm{b}}$ National Autonomous University of Mexico, Physics Institute. Address: Circuito de la Investigación Cientifica s/n, Ciudad Universitaria, Coyoacán, 04510, Mexico.

' Autonomous University of Sinaloa, Faculty of Odontology. Address: Blvd. de las Américas y Universitarios, 80010 Culiacán, Sinaloa, Mexico.

d Faculty of agronomy, autonomous University of Sinaloa, carretera Culiacán-El Dorado km 17.5 Apdo postal 726 Culiacán de Rosales, Sinaloa, Mexico.
} 


\section{INTRODUCTION}

The study of archaeological resins can give information relative to the man-environment relationship, the ethnology and technological knowledge of civilizations. In the case of Aztecs, these information are highly valuable because of the lack of documents on pre-Columbian period.

Between 2006 and 2008 archaeological excavations took place at Templo Mayor Site, and a resinous material attracted the attention of archaeologists and conservation professionals, because of their abundant presence in offerings, their versatile use, but also of the diversity on conservation states related to degradation, involving changes in color and surface texture. About offerings context, copal was used as molding material for figurines, spiritual offering and adhesive. To our knowledge formulations related to different uses have never been studied before and the botanical origin of the employed resins is a major concern within archaeobotanic research field.

\section{Historical background and copal in ancient Mexico}

The knowledge of art crafts manufacturing in Ancient Mexico is quite ambiguous and most of the time is fragmentary and scarce, due to the lack of documentary sources. This research focuses on the study of two amorphous artifacts, collected from offerings 120 and 126 at Templo Mayor. Table 1 provides additional information about these materials.

The "Templo Mayor" was built on the geographical center of Mexico City. It was a precinct surrounded by a staggered platform, on which the main buildings of the city where located. It was the tributary center of the Empire.
Merchandises from a vast territory either sold in markets or paid as tribute (Carrasco, 1999), were put together in offerings and funerary deposits. In this temple, took place all ritual celebrations: from the regular ones, marked in preColumbian calendar to the most extraordinary ones corresponding to the enthronization and funerary ceremonies for the emperor (Lopez-Luján and Chavez, 2010). In each of these events offerings were buried (Matos-Moctezuma, 2011). When Aztecs arrived to Mexico Valley the Tecpanecs from Azcapotzalco dominated the region. After a short period they established in Chapultepec from which they were expelled. Then they settled in Tizapan a territory dominated by Culhuacan, but they left this settlement because of the hostile environment. The Mexicas or Aztecs were an ethnic group with nahua filiation. After a long peregrination, they funded Mexico-Tenochtitlan, a city that between the XVth and XVIth centuries became the center of one of the biggest empires in Mesoamerica. Aztecs developed one of the richest and more complex religious, political, cosmologic, astronomic, philosophic and artistic traditions.

The offerings found in the Templo Mayor of Tenochtitlan are made by sets of objects carefully ordered in layers (López-Lújan, 1993). Some of these were placed in stone boxes underneath the buildings, whereas others were buried directly in the constructive filling materials between constructive stages of Templo Mayor pyramid. Among the elements gotten back from these offerings were: figurines representing deities, scepters, a pectoral, masks, lappets, flutes, whistles, drums, instruments of sacrifice, a wooden mask, flora and fauna remains, etc (López-Lújan and Chavez, 2010). The first Spanish people on American continent kept the Mexican term "copal" as well as the term "incienso de indias" (incense from India) to refer to the natural resins, produced by New World trees, that were

\begin{tabular}{|c|c|c|c|c|c|c|}
\hline ID & Artifact number & $\begin{array}{c}\text { Nature of the } \\
\text { material }\end{array}$ & $\begin{array}{c}\text { Weight of sample } \\
(\mathrm{g})\end{array}$ & $\begin{array}{c}\text { Number of } \\
\text { Offering }\end{array}$ & Picture & Scale \\
\hline A & A 252 & $\begin{array}{c}\text { Amorphous mate- } \\
\text { rial }\end{array}$ & 0.04 & 126 & $5 \mathrm{~mm}: 80 \mathrm{x}$ \\
\hline B & Unknown & $\begin{array}{c}\text { Amorphous mate- } \\
\text { rial }\end{array}$ & 0.32 & 120 & $5 \mathrm{~mm}: 25 \mathrm{x}$ \\
\hline
\end{tabular}

Table 1: Archaeological samples information

Tableau 1 : Informations sur les échantillons archéologiques 
burnt during religious ceremonies, probably because of the parallel use in Europe of Boswellia resins (frankincense). Mesoamerican cultures considered copal as a protector. The representation of copal can often be found in codex where priest are offering it to the gods. In goldsmith, copal was used as wax is used in nowadays, in the "lost wax" technique. It was part of the formulas that were used as adhesives for masks, small rocks, and even in dentistry where it was used in dental incrustations, in teeth cavities and in dental restorations as well (Bucio et al, 2006).

\section{Natural plant resins: botanic and chemical composition}

To our knowledge few researches deal with the chemical composition of mexican copal. Some articles describe Mexican commercial resins (De-la-Cruz-Cañizares et al., 2005; Orta-Amaro, 2007; Vandenabeele et al., 2007; Hernández-Vázquez et al., 2010;) and it is possible to find papers based on the study of archaeological objects (Magar and Menar,1995; Stacey and Cartwright, 2006 and Vandenabeele, 2003). They respectively analyzed a turquoise mosaic, a series of objects from the British Museum and a figure molded in resin. Finally a recent study from our research team (Lucero-Gómez, 2012, Lucero-Gómez et al., 2014) focused only on the study of the triterpenic composition of certified origin resins.

Mexican copal resins are produced by trees that belong to the genus Bursera spp. from Burseraceae family. Currently, in Mexico, there are more than 80 species of resin producing Bursera trees (Rzendowski et al., 2005). Bursera species are highly resinous and release a characteristic pine-lemony odor when a leaf or branch is broken. The smell is due to highly volatile terpene compounds such as $\alpha$-pinene, $\beta$-phelandrene, limonene, carene, etc. (Becerra et al., 2001). Oleoresins are referred to as "oilyresins" when they are very fluid. This fluidity is due to a high ratio of volatile to nonvolatile terpenes (Langenheim, 2003).

In Burseraraceae, triterpenoids are the primary components of the non-volatile fraction.

It is important to note that some other substances can be intermixed or mistaken with resins, among which gums can be mentioned (Langenheim, 2003). Chemically gums are composed of complex chains of hydrophilic polysaccharides derived from monosaccharide molecules such as galactose, arabinose, and rhamnose. Whistler (1993) described in detail the very complex structure of exudated gums.

Given the large number of possible botanical origins for historical samples, the purpose of this research was to establish molecular profiles that allow the discrimination of botanical origin of samples, so it was necessary to analyze resins from botanically-certified origin. The choice of the botanical species was based on specialized literature and more precisely on previous works about Mexican copal (Magaloni et al., 1993; Stacey and Cartwright, 2006; Montúfar, 2007; Hernández-Vázquez et al,.2010) to increase the possibilities of achieving our goal. Six species were selected for this study: B. bipinnata, B. stenophylla, B. simaruba, B. excelsa, B. laxiflora and B. penicillata.

The difficulty of plant resins analyses relies on the fact that no general analytical technique exists to characterize the molecules entering in their composition and their degradation products (Colombini et al., 2000). The second difficulty in analyzing these materials by HPLC relies on the nature of the resins themselves, which are chemically very complex (Witte et al., 1986). Indeed, Bursera resins consist of a wide variety of compounds with very similar structures. This molecular complexity increases with degradation process. Additionally, analysis of archaeological samples is difficult because of the restrictions on the number of samples and their size.

\section{Chemometrical Approach}

HPLC-UV/Vis is a reasonably sensitive analytical tool that allows molecular profiling. In this research, this technique was used coupled to two multistatistical methods PCA (Principal Component Analysis) and LDA (Linear Discriminant Analysis).

A number of papers have identified natural materials by means of chemometric approaches (Tapp et al., 2003; Rezzi et al., 2005; Armanino et al., 2008; Casale et al., 2010a, Casale et al.,2010b). The most common is PCA (Principal Component Analysis), which has been applied to the discrimination of proteinaceous media (Colombini et al., 1999; Andreoti et al., 2006; Bonaduce et al., 2006; Gautier and Colombini, 2007), drying oils (Andreoti et al., 2006; Colombini et al, 1999), polysaccharides (Colombini et al, 2002) and resins (Vieillescazes et al, 1996).

In the present work, this approach allowed a better discrimination of chromatographic profiles in order to enhance interpretation of analytical results. A description of the statistical tools employed can be found in the methods section of this work.

\section{Material AND METHOdS}

A protocol using HPLC (High Performance Liquid Chromatography) was employed in this research. 
Chromatographic techniques are powerful tools applied in several laboratories specialized in artworks because of their ability to separate organic compounds from complex mixtures (Doménech-Carbó, 2008).

\section{Statistical Methods: Principal Component Analysis (PCA)}

The aim of this method is to capture the intrinsic variability in the data and at the same time, to reduce the dimensionality of a data set, either to ease interpretation or as a way to avoid overfitting and to prepare for further analysis (Terradez, 2000). In this way PCA succeeds in explaining the maximum amount of variance with the fewest number of main components (the smallest loss of information). Principal components are linear combinations of the original variables with the first principal component having the largest variance, the second having the second largest variance and so on (Cosio et al, 2007). PCA also allows considering the preferred directions of the data and ignoring the variables that do not have a big influence in the separation of the groups (Barreto, 2009). When data is projected in two dimensions (or three), it is possible to distinguish visually the different classes that could appear, grouped in the projection. The different classes will be formed by those observations that display an uniform behaviour to each other and differ from other existing groups (García, 2002).

\section{Statistical Methods: Linear discriminant analysis (LDA)}

LDA is a powerful chemometric tool that allows finding a predictive classification model, meaning that it allows the construction of a model able to foretell the property of a sample according to a previously defined category, or to investigate the way variables contribute to the separation in categories. This means that it allows studying the degree in which different populations, established a priori, differ from each other. It deals with two kinds of problems: descriptive discrimination, in which it describes how two (or more) populations differ from each other; and classification in strict sense, in which there are two or more given populations and an object that can belong to one of them. The discriminating analysis requires to obtain a linear (or nonlinear) combinations of independent variables that will discriminate between defined groups a priori, so that the errors of the wrong classification must be minimum (Barreto, 2009).

The LDA model is based on a set of samples of wellknown category, called training data set, and then a regres- sion equation is used as discriminating function (Casale $e t$ al, 2010a).

Once the model is obtained, it is used for the prediction of the category of property of the samples of unknown category. LDA can be linear or quadratic. The linear model assumes that all the groups have the same covariance matrix, while quadratic ones do not make this assumption.

In this research a level-one-out procedure was used. This means that each sample was once removed from the data set. The classification model is rebuilt and the removed sample is classified in this new model. All the samples of the data set are sequentially removed and reclassified. Finally a percentage of the correct classification is calculated (Lachlan, 1992). The quality of the LDA classification model was modeled according to the basis of the validation results. The statistic analysis (PCA and LDA) in this work was performed using Minitab 16 (Minitab Inc. PA, California).

\section{Reagents}

Standard molecules were used for their identification in molecular composition of archaeological resins: $\alpha$-amyrin, $\beta$-amyrin, lupeol, and lupenone were purchased from Extrasynthèse (Genay, France), while $\alpha$-amyrone and $\beta$-amyrone were purchased from BCP instruments (Irigny, France), 3-epi-lupeol, 3-epi- $\alpha$-amyrin, 3-epi- $\beta$-amyrin were isolated by our team from commercial resin samples (Culioli et al, 2003).

\section{Samples of resin from botanical certified origin}

Certified resin samples from six species of Bursera trees were collected in Mexican territory. The choice of these particular species was defined by two factors: previous research results (Stacey and Cartwright 2006; Montúfar, 2007 and Hernández-Vázquez 2010) and to obtain an overview on the variability of the chemical composition of Bursera resins from Mexico. Moreover, to rule out different molecular compositions of resin from the same species, samples were taken from different trees.

For the collection of the certified-origin samples, this research was realized with the invaluable collaboration of experts in botanic (Dr. Rito Vega) and in biomaterials (Dr. Irma Belio) from the Autonomous University of Sinaloa (UAS), as well as with the cooperation of the academic team of Biomaterials from the UAS (UAS CA-208). The collection was realized from summer to fall, period during trees have both leaves and fruits, which are necessary for botanical identification. After practicing a small cut into tree barks, resin was collected in glass tubes. In table 2 , information 
relating the number of samples for each species and their geographical location (GPS position) are presented.

Table 2]

\section{Historical samples}

The two archaeological samples come from offerings discovered at Templo Mayor Site. Sample referred "A" comes from offering 120 while sample " $B$ " comes from offering 126 , both offerings were unearthed in a lot where once stood a colonial building known as "Casa de las Ajaracas". The principal stairs of the sixth constructive stage of the Templo Mayor were built in the same physical space that "Casa de las Ajaracas" (Matos, 2007).

\section{Gum analysis}

The aim ofthese analyses is to evaluate the gum percentage in the raw resinous material. The gum part is hydrosoluble and the resinous part is soluble in methanol. This study was performed solving a known amount of fresh resin in methanol. After sonication and centrifugation, the residue left in the bottom of the solution was dried and weighed. The percentage of gum was calculated from this data. Finally, water was added to ensure the polarity of the residue and to verify its total solubility.

\section{Analytical conditions in HPLC-UV/Vis}

For the HPLC study, both standards and global resins were solved in methanol (analytical grade, Merck). The protocol consists in solubilizing an amount of crude resin (variable depending on botanical origin) in $2 \mathrm{~mL}$ of this solvent, then the solution was sonicated during $10 \mathrm{~min}$. After centrifugation, the supernatant was injected into the HPLC system. Each sample was injected in triplicate to ensure reproducibility of the results.
Analyses were performed using a reverse phase column with an elution gradient. The type of column used in this research field is essential, taking into account the previous results obtained by our team. Indeed, these works (Mathe $e t$ $a l, 2004)$, showed that for resins, a column in reverse phase C18 led to satisfactory separations and resolutions of the compounds. This study was thus carried out using a column with non-polar stationary phase Merck Lichrocart Purostar $5 \mu \mathrm{m} 100 \mathrm{RP}-18 \mathrm{e} 250 \mathrm{~mm}$ x 4 mm (Merck, Darmstadt, Germany).

LC-PDA analysis was carried out in a Waters liquid chromatograph consisting of a high-pressure ternary pump Waters 600, a vacuum degasser, a high pressure manual injection valve $(20 \mu \mathrm{L}$ injection loop) and a photodiode array detection (PDA) system Waters 2996. The system was controlled by Empower 2 software. The LC separation was performed at $35^{\circ} \mathrm{C}$ with a mobile phase consisting of a binary elution composed of (A) bidistilled water containing $0.01 \%$ trifluoroacetic acid (TFA) and (B) methanol analytical grade (Merck). The chromatograms were acquired at $210 \mathrm{~nm}$. Identification of original triterpenoids was based on the co-injection of samples with reference molecules. Chromatographic analyses of standard molecules, certified resins and archaeological sample A were carried out for 35 $\mathrm{min}$ at a continuous flow-rate of $1 \mathrm{~mL} / \mathrm{min}$. For the study of archeological sample $\mathrm{B}$, a prolonged gradient was necessary as compounds that were not present in fresh samples were detected. The gradient profile is presented in table 3.

\section{Results OF HPLC-UV/Vis STUdY}

\section{Standard molecules}

Liquid chromatography was applied to the study of six standard molecules (table 4) at $210 \mathrm{~nm}$, which is the general wavelength number for the study of resins (Büchele et al, 2003; Mathe et al, 2004).

\begin{tabular}{|c|c|c|c|c|}
\hline Botanical species & $\begin{array}{c}\text { Number of collected } \\
\text { samples }\end{array}$ & $\begin{array}{c}\text { Date of collection } \\
(\mathbf{d d} / \mathrm{mm} / \mathrm{yyyy})\end{array}$ & \multicolumn{2}{|c|}{ GPS localization } \\
\hline B. bipinnata & 11 & $09 / 08 / 2010$ & $25^{\circ} 07^{\prime} 21.42^{\prime} \mathrm{N}$ & $107^{\circ} 11^{\prime} 57.42^{\prime} \mathrm{W}$ \\
\hline B. excelsa & 4 & $05 / 09 / 2009$ & $24^{\circ} 50^{\prime} 37.62^{\prime} \mathrm{N}$ & $107^{\circ} 02^{\prime} 28.76^{\prime} \mathrm{W}$ \\
\hline B. laxiflora & 14 & $01 / 11 / 2009$ & $24^{\circ} 45^{\prime} 36.06^{\prime} \mathrm{N}$ & $107^{\circ} 11^{\prime} 51.48^{\prime} \mathrm{W}$ \\
\hline B. penicillata & 6 & $29 / 08 / 2009$ & $24^{\circ} 46^{\prime} 08.64^{\prime} \mathrm{N}$ & $107^{\circ} 09^{\prime} 28.26^{\prime} \mathrm{W}$ \\
\hline B. simaruba & 15 & $01 / 11 / 2009$ & $24^{\circ} 51^{\prime} 27.60^{\prime} \mathrm{N}$ & $107^{\circ} 01^{\prime} 07.02^{\prime} \mathrm{W}$ \\
\hline B. stenophylla & 8 & $19 / 09 / 2009$ & $26^{\circ} 41^{\prime} 26.40^{\prime} \mathrm{N}$ & $108^{\circ} 19^{\prime} 58.70^{\prime} \mathrm{W}$ \\
\hline
\end{tabular}

Table 2: Number of certified samples studied and their geographical location

Tableau 2 : Nombre d'échantillons certifiés étudiés et leur emplacement géographique 


\begin{tabular}{|c|c|c|c|c|c|}
\hline Time (min) & $\mathbf{0}$ & $\mathbf{1 0}$ & $\mathbf{1 5}$ & $\mathbf{3 5}^{\mathbf{a}}$ & 100 \\
\hline$\%$ Methanol & 85 & 95 & 100 & 0 & 100 \\
\hline$\% \mathrm{H}_{2} \mathrm{O}-\mathrm{TFA}$ & 15 & 5 & 0 & 0 \\
\hline \multicolumn{2}{|l|}{ Flow $: 1 \mathrm{~mL} \cdot \mathrm{min}^{-1}$} & \multicolumn{2}{c|}{ Temperature of the column $=35^{\circ} \mathrm{C}$} \\
\hline
\end{tabular}

Table 3: HPLC gradient profil ( ${ }^{a}$ Final run time for standard molecules, certified resins and archaeological sample A; ${ }^{\mathrm{b}}$ Final run time for sample B).

Tableau 3: Gradient CLHP (a Temps final d'analyse pour les molécules standards, les résines certifiées et l'échantillon archéologique A; ${ }^{b}$ Temps final d'analyse pour l'échantillon archéologique B).

Their retention time under the designed gradient is shown in table 4 . These triterpenes were assigned by a number, according to their elution order. Number assignment will be kept all along this paper for the identification of these molecules in chromatograms.

\section{Results of HPLC-UV/Vis study on certified resins samples}

The first difficulty for the study of resins by HPLC-UV/ Vis arose because of the need of different amounts of sample depending on the apolar molecules content of the studied species: going from $2 \mathrm{mg}$ up to $30 \mathrm{mg}$, as referred to in table 5.

The amount of resin needed for the analysis has been directly correlated to the amount of gum present in the sample: the higher amount of gum was, the rarer apolar compounds were (terpenoids included) and so, the more important the sample amount needed for the analysis

Table 5 also sums up the percentage of gum found in each studied species. Generally gum ratio is correlated to the producing species but this fact alone cannot constitute a factor for botanical identification, as gums are water soluble, widely distributed, and easy degradable materials. The important proportion of gum in $B$. simaruba exudates provided chromatograms with less resolved peaks than in other species, therefore the results of analysis of this species could not be treated by PCA and LDA statistical analysis.

Chromatograms in liquid phase allowed a very clear interspecies distinction. It is note-worthy that two separated areas were distinguished in each chromatogram: the first one going from 0 to 24 minutes and the second running from 24 to 35 minutes. The first zone corresponds to components with lower molecular weight and highest polarity. This first molecular population was characterized by a succinct LC-SM analysis as sesquiterpenes, however these peaks cannot be surely assigned in the context of this article. The second group of peaks in the chromatogram corresponds to molecules of higher molecular weight and lower polarity; nine of the eleven molecules detected in this

\begin{tabular}{|c|c|c|}
\hline $\mathbf{N}^{\circ}$ & Molecule & Retention time (min) \\
\hline $\mathbf{1}$ & 3-epi-lupeol & 26.5 \\
\hline $\mathbf{2}$ & lupeol & 27.6 \\
\hline $\mathbf{3}$ & 3-epi- $\beta$-amyrin & 28.2 \\
\hline $\mathbf{4}$ & lupenone & 28.7 \\
\hline $\mathbf{5}$ & 3-epi- $\alpha$-amyrin & 29.4 \\
\hline $\mathbf{6}$ & $\beta$-amyrin & 29.9 \\
\hline $\mathbf{7}$ & $\alpha$-amyrin & 31.3 \\
\hline $\mathbf{8}$ & $\beta$-amyrone & 31.4 \\
\hline $\mathbf{9}$ & $\alpha$-amyrone & 32.2 \\
\hline
\end{tabular}

Table 4: Retention time of standard molecules Tableau 4 : Temps de rétention des molécules standards

\begin{tabular}{|l|c|c|c|}
\hline & $\begin{array}{c}\text { Mass of sample used for } \\
\text { HPLC analysis }\end{array}$ & $\begin{array}{c}\text { \% } \\
\text { Gum }\end{array}$ & $\begin{array}{c}\text { \% } \\
\text { Resin }\end{array}$ \\
\hline B. bipinnata & $3 \mathrm{mg}$ & 0 & 100 \\
\hline B. excelsa & $6 \mathrm{mg}$ & 0.5 & 99.5 \\
\hline B. simaruba & $30 \mathrm{mg}$ & 25 & 75 \\
\hline B. penicillata & $3 \mathrm{mg}$ & 0 & 100 \\
\hline B. stenophylla & $3 \mathrm{mg}$ & 0 & 100 \\
\hline B. laxiflora & $6 \mathrm{mg}$ & 8 & 92 \\
\hline
\end{tabular}

Table 5: Amount of resins used for the HPLC chromatographic study and gum-resin percentage in resin samples from certified species.

Tableau 5: Quantité de résines employée pour l'analyse chromatographique et pourcentage en gomme-résine des résines certifiées botaniquement.

region were identified by co-injection with standard molecules as triterpenes.

Figure 1 shows a chromatogram of B. bipinnata where the two above mentioned areas of peaks are distinguished: marked with a continuous arrow the more polar zone, and with a dotted one the triterpenoid zone. For the first part of the chromatogram we chose a notation for compounds beginning either with letters $\mathrm{A}$ or $\mathrm{B}$.

Compounds noted "A" are widely distributed in the six species, most of the time A1 is a major peak in the chromatograms. These peaks were present also in chromatograms of 


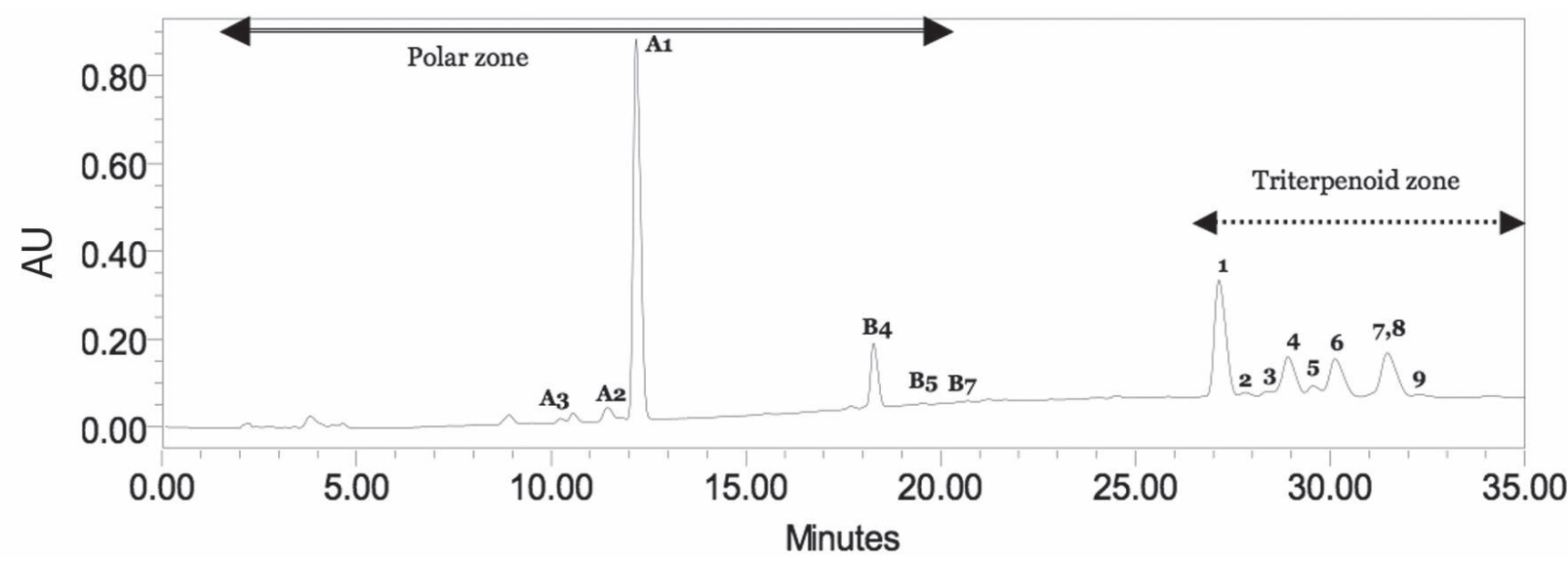

Figure 1: Chromatogram of B. bipinnata (sample 11d2), triterpenoid zone running from 24 to 35 min in retention time. (1) 3-epi-lupeol, (2) lupeol, (3) 3-epi- $\beta$ amyrin, (4) lupenone, (5) 3-epi- $\alpha$ amyrin, (6) $\beta$-amyrin, (7/8) $\alpha$-amyrin/ $\beta$-amyrone, (9) $\alpha$-amyrone).

Figure 1 : Chromatogramme de B. bipinnata (échantillon 11d2), agrandissement de la zone triterpénique de 24 à 35 min. (1) 3-épi-lupéol, (2) lupéol, (3) 3-épi- $\beta$ amyrine, (4) lupénone, (5) 3-épi- $\alpha$ amyrine, (6) $\beta$-amyrine, (7/8) $\alpha$-amyrinel $\beta$-amyrone, (9) $\alpha$-amyrone).

archaeological samples. While "B" compounds are specific for each species, meaning that their presence and quantity varies a lot among studied species and were almost absent from archaeological samples.

Table 6 resumes the presence and absence of compounds of lower molecular weight and higher polarity, and table 7 sums up the presence and absence of triterpenoids related to botanical origin.

Concerning resolution of peaks, in our analytical conditions, it was impossible to separate the signals from $\alpha$-amyrin (7) and $\beta$-amyrone (8), which is not surprising as both compounds have a similar molecular structure.
The closest triterpenic molecular composition was found between B. bipinnata and B. stenophylla species. A difference between B. bipinnata and B. stenophylla, lies in the absence of triterpenic compounds $\mathrm{T} 1$ at $25.4 \mathrm{~min}$ and $\mathrm{T} 2$ at 33.5 min in B. bipinnata (Table 7, Figure 2). Gum was absent of the composition of both species.

Concerning B. excelsa it was the species that displayed the poorest composition in the triterpenic zone, only four compounds were detected by HPLC-UV/Vis: lupeol (2), 3-epilupeol (3), lupenone (4) and $\beta$-amyrin (6). Nevertheless relative peak areas of $\beta$-amyrin (6) and lupenone (4) were considerably smaller than the ones for those of the other two

\begin{tabular}{|c|c|c|c|c|c|c|c|c|c|c|c|c|}
\hline ID of the peak & A4 & A3 & A2 & A1 & B1 & B2 & B3 & B4 & B5 & B6 & B7 & B8 \\
\hline Ret. time (min) & 8.9 & 10 & 11.4 & 12 & 16 & 16.5 & 17 & 18 & 19.4 & 20 & 20.6 & 24 \\
\hline B.bipinnata & - & + & + & + & - & - & - & + & + & - & + & - \\
\hline B. stenophylla & + & + & + & + & - & - & - & + & + & - & + & + \\
\hline B. excelsa & - & + & - & + & + & - & - & - & + & + & - & + \\
\hline $\begin{array}{l}\text { B. laxiflora } \\
\text { (profile A) }\end{array}$ & + & + & + & + & + & + & - & - & - & - & - & + \\
\hline $\begin{array}{l}\text { B.laxiflora } \\
\text { (profile B) }\end{array}$ & - & - & + & + & + & + & - & - & - & - & - & + \\
\hline B. penicillata & - & - & - & + & + & - & + & + & + & - & - & - \\
\hline B. simaruba & - & + & + & + & - & - & - & - & - & + & - & - \\
\hline $\begin{array}{l}\text { Archaeological } \\
\text { sample A }\end{array}$ & - & + & - & + & - & - & - & + & - & - & + & + \\
\hline $\begin{array}{l}\text { Archaeological } \\
\text { sample B }\end{array}$ & + & - & - & + & - & - & - & + & - & - & - & - \\
\hline
\end{tabular}

Table 6: Retention time of peak corresponding to non triterpenic compounds observed in each species (+ presence, - absence) Tableau $6:$ Temps de rétention des pics correspondants aux composés non triterpéniques de chaque résine (+ présence, - absence). 


\begin{tabular}{|c|c|c|c|c|c|c|c|c|c|c|}
\hline ID of the peak & T1 & 3-epi-lupeol & lupeol & $\begin{array}{l}\text { 3-epi- } \beta \\
\text { amyrin }\end{array}$ & lupenone & $\begin{array}{c}\text { 3-epi- } \alpha \\
\text { amyrin }\end{array}$ & $\beta$-amyrin & $\begin{array}{c}\alpha \text {-amyrin } / \beta \\
\text {-amyrone }\end{array}$ & $\alpha$-amyrone & T2 \\
\hline Ret. time (min) & 25.5 & 26.5 & 27.6 & 28.2 & 28.7 & 29.4 & 29.9 & 31.3 & 32.1 & 33.5 \\
\hline B.bipinnata & - & + & + & + & + & + & + & + & + & - \\
\hline B. stenophylla & + & + & + & + & + & + & + & + & + & + \\
\hline B. excelsa & + & + & + & - & + & - & + & - & - & - \\
\hline $\begin{array}{l}\text { B.laxiflora } \\
\text { (profile A) }\end{array}$ & - & + & + & + & + & - & + & + & + & - \\
\hline $\begin{array}{l}\text { B.laxiflora } \\
\text { (profile B) }\end{array}$ & - & + & + & - & + & + & + & + & + & - \\
\hline B. penicillata & - & + & + & + & + & + & + & + & + & - \\
\hline B. simaruba & - & + & + & + & + & + & + & + & + & - \\
\hline$\underset{\text { A }}{\text { Archaeological sample }}$ & - & + & + & - & + & + & + & + & + & + \\
\hline$\underset{\text { B }}{\text { Archaeological sample }}$ & - & + & + & - & + & + & + & + & + & + \\
\hline
\end{tabular}

Table 7: Retention time of peaks corresponding to triterpenic compounds (+ presence, - absence).

Tableau 7 : Temps de rétention des pics des composés triterpéniques (+ présence, - absence).

\section{A) B. bipinnata}

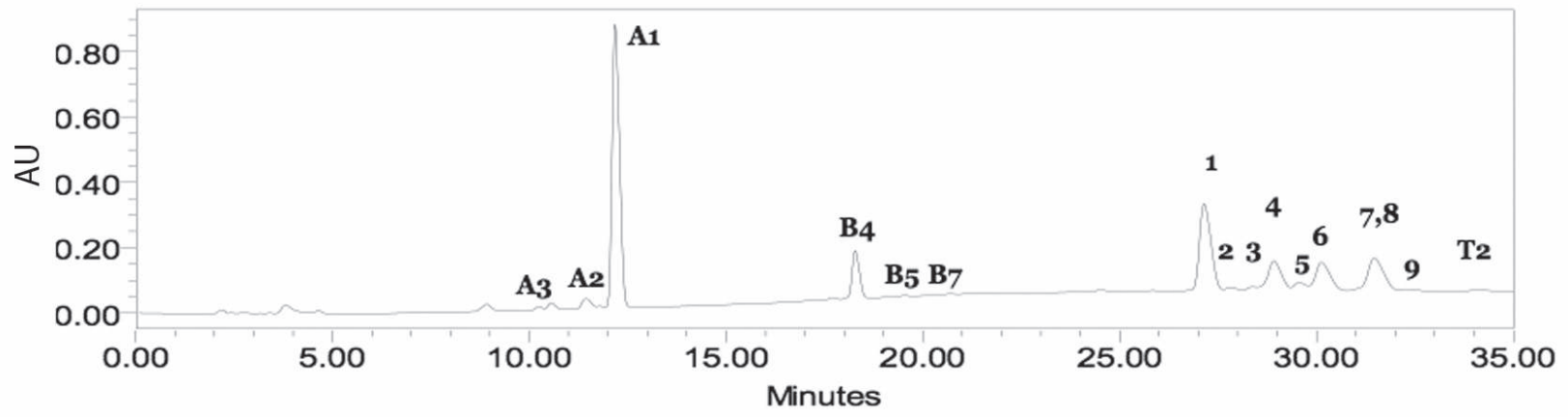

\section{B) B. stenophylla}

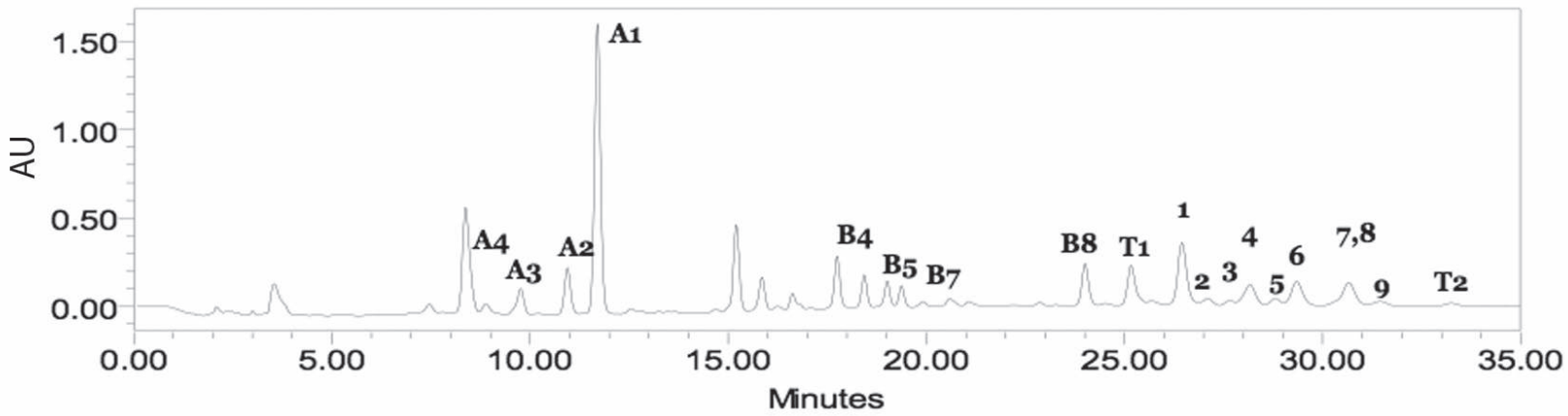

Figure 2- Comparison of A) B. bipinnata and B) B. stenophylla chromatograms. (1) 3-epi-lupeol, (2) lupeol, (3) 3-epi- $\beta$-amyrin, (4) lupenone, (5) 3-epi- $\alpha$ amyrin, (6) $\beta$-amyrin, (7/8) $\alpha$-amyrin/ $\beta$-amyrone, (9) $\alpha$-amyrone.

Figure 2- Comparaison des chromatogrammes de A) B. bipinnata et B) B. stenophylla. (1) 3-épi-lupéol, (2) lupéol, (3) 3-épi- $\beta$-amyrine, (4) lupénone, (5) 3-épi- $\alpha$ amyrine, (6) $\beta$-amyrine, (7/8) $\alpha$-amyrinel $\beta$-amyrone, (9) $\alpha$-amyrone. 
compounds, and in the apolar zone A1 was the major peak. On the other hand gum content of samples of this resin reaches almost zero $(0.5 \%)$.

B. simaruba resin exhibited the higher content of gum (25\%). The presence of gum complicated HPLC analysis: resolution of peaks corresponding to triterpenes in its chromatograms was poorer, three clumps of peaks were observed, the first one consisting of 3-epi-lupeol, lupeol, 3 -epi- $\beta$-amyrin and lupenone while the second one 3-epi- $\alpha$ amyrin and $\beta$-amyrin, the third included the peak comprising $7 / 8 \alpha$-amyrin/ $\beta$-amyrone like the other species plus $\alpha$-amyrone, and in the more polar zone of the chromatogram A1 was outnumbering the other peaks.

B. penicillata exhibited a high number of peaks in the first zone of the chromatogram, where A1 was the highest, other peaks with high relative area were B2, B3 and B5. Concerning the triterpenic zone, nine standard molecules were identified; the only triterpenes absent from its composition were $\mathrm{T} 1$ and $\mathrm{T} 2$.

Finally B. laxiflora resins were the ones that displayed the greater diversity in molecular composition in this study. Among the samples analyzed, two lots could be distinguished, given their diverse molecular profile. Nevertheless some common features could be distinguished between the two lots: B1 had the peak with the biggest area in all the cases. Concerning triterpenic fraction, the relative peak area of triterpenic compounds was rather small. In "lot a", triterpenic most important peaks were those from 3-epi-lupeol, lupeol and 3-epi- $\beta$-amyrin, while in "lot b" the main signal in the triterpenic zone was 3-epi-lupeol.

\section{Results of HPLC-UV/Vis study on archaeological resins}

In archaeological samples, the percentage of gum was nul: this fact can be correlated either to the botanical origin of the sample or to the fact that these samples were exposed during a long time to high moisture and even under-water conditions. Nevertheless sample B contained a small proportion (1.73) of matter that was not soluble in our experimental conditions. The small amount of this material available for analysis prevented further studies on its nature.

Despite the age of archaeological samples and their preservation under different conditions of relative humidity, $\mathrm{pH}$ and temperature, their molecular composition (appearing in chromatograms) retained most of the triterpenic fraction compounds except for 3-epi- $\beta$-amyrin and T1, as it has been said above. Within the more polar fraction the most important signal arose from compound A1.
The exceptional conservation state of these samples can be attributed to burial anoxic environment with a high humidity level, the absence of light, and more or less stable temperature.

HPLC chromatogram profiles from Aztec materials coming from Templo Mayor may suggest that they are either from B. bipinnata or B. stenophylla. In order to enhance the exploitation of these results, and to find a more concrete answer regarding the botanical origin of these samples, two statistical methods were used to analyze the data.

Concerning the molecular profile, the archaeological samples studied were different: in sample B four molecules that were not present in fresh samples were detected, this was the reason that made the use of a longer gradient necessary. These compounds were absent from sample A.

In figure 3, the chromatogram corresponding to sample $\mathrm{B}$ is displayed; the peaks can be appreciated from 32.5 to 36 min identified as $\mathrm{C} 1$ to $\mathrm{C} 3$. These compounds may correspond to apolar molecules. In figure 4 , the chromatogram of sample A is presented.

From these chromatograms, important informations can be extracted concerning ageing: some molecules disappeared in some cases like A2, A3, B8 Molecules that were totally absent from these samples and that therefore are more prone to degradation are: $\mathrm{B} 1, \mathrm{~B} 2, \mathrm{~B} 3$ and $\mathrm{B} 5$.

Finally sometimes molecules related to ageing like $\mathrm{C} 1$ to C3 may appear. However some compounds resist to ageing like triterpenes (1-8).

\section{HPLC coupled to PCA analysis for botanical certified resins}

For this study, both polar (table 6) and triterpenic compounds (table 7) were taken into account. Peak areas from chromatograms were used in an indirect way: as HPLC analyses were performed on different amounts of crude resin, we chose to use the relative area percentage of each peak for PCA and LDA analysis.

B. simaruba was excluded from statistical analysis because of the poor resolution achieved that prevented distinction of the peaks of triterpenic compounds. A data matrix with 40 rows (resin of certified origin samples) and 22 columns (variables, in this case relative area percentage of the assigned peaks in the chromatogram) was built. Figure 5 shows the graphic results of PCA. The structure of the data, using the first two principal components is displayed.

In this case the first two principal components were enough to display the data structure, and they explained $46.5 \%$ of the total variance. By examining the score plot in the area defined by the first two principal components, 


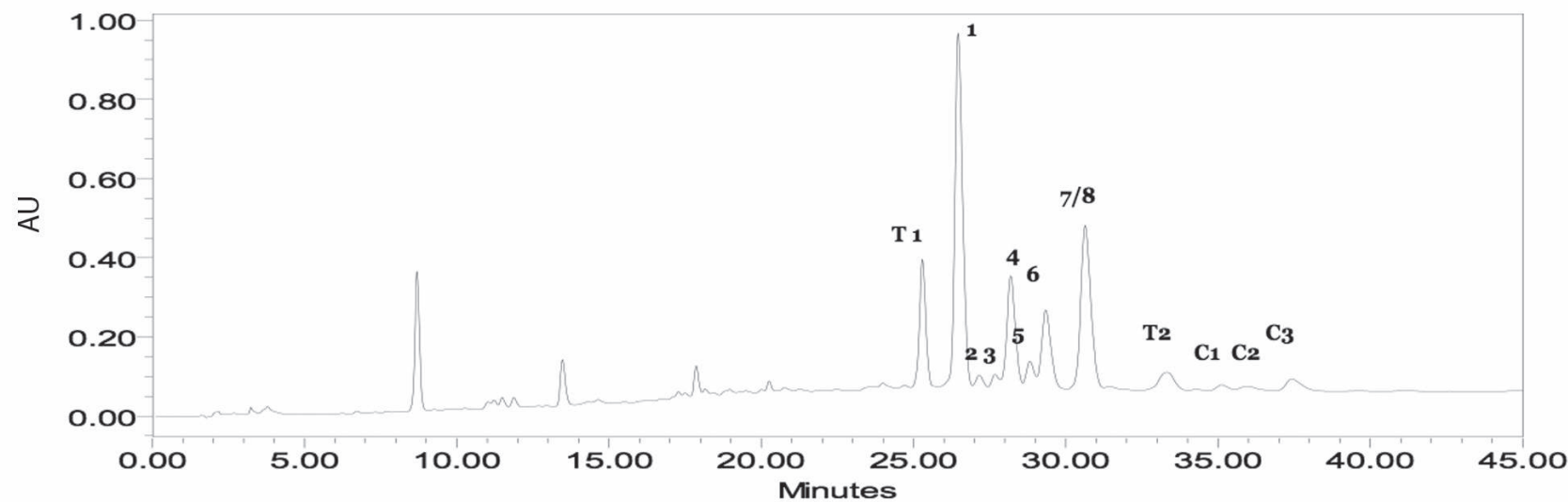

Figure 3: Chromatogram of archeological sample B with triterpenes and ageing related products (C1-C3). 1) 3-epi-lupeol, 2) lupeol, 3) 3 -epi- $\beta$-amyrin, 4) lupenone, 5) 3-epi- $\alpha$ amyrin, 6) $\beta$-amyrin, 7/8 $\alpha$-amyrin/ $\beta$-amyrone.

Figure 3 : Chromatogramme de l'échantillon archéologique B avec la présence de triterpènes et de composés de dégradation (C1-C3). 1) 3-épilupeol, 2) lupéol, 3) 3-épi- $\beta$-amyrine, 4) lupénone, 5) 3-épi- $\alpha$ amyrine, 6) $\beta$-amyrine, $7 / 8 \alpha$-amyrinel $\beta$-amyrone.

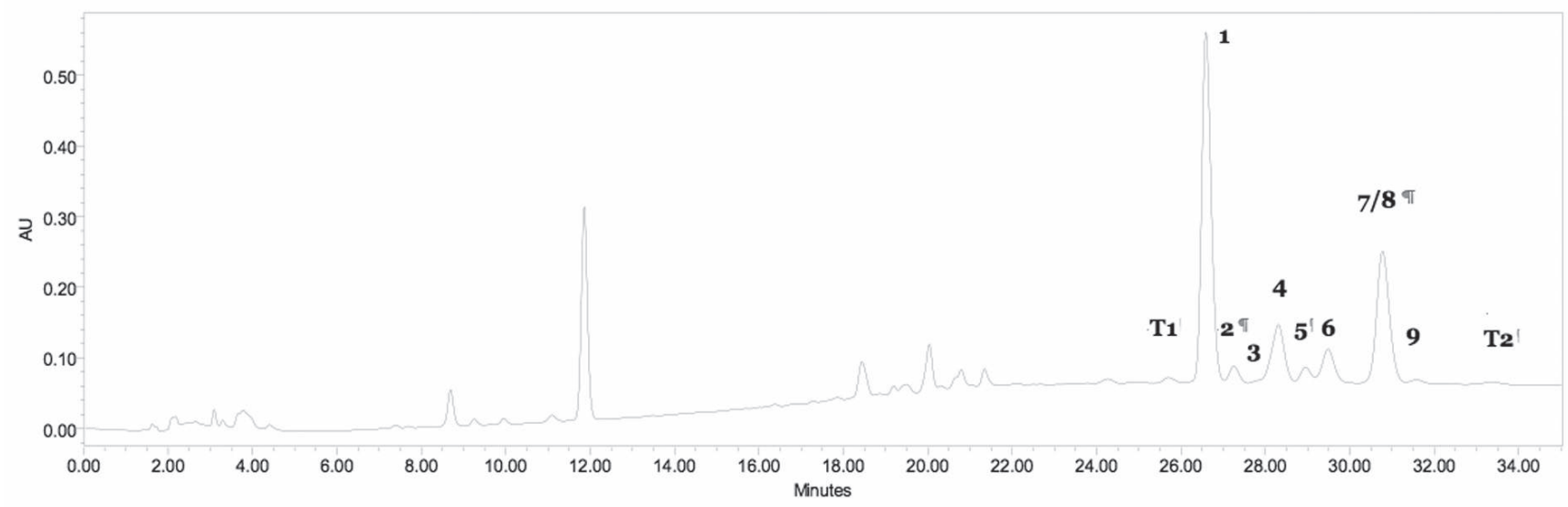

Figure 4: Chromatogram from archeological sample A. 1) 3-epi-lupeol, 2) lupeol, 3) 3-epi- $\beta$-amyrin, 4) lupenone, 5) 3-epi- $\alpha$ amyrin, 6) $\beta$-amyrin, $7 / 8 \alpha$-amyrin/ $\beta$-amyrone, 9) $\alpha$-amyrone.

Figure 4: Chromatogramme de l'échantillon archéologique A.1) 3-épi-lupéol, 2) lupéol, 3) 3-épi- $\beta$-amyrin, 4) lupénone, 5) 3-épi- $\alpha$ amyrine, 6) $\beta$-amyrine, $7 / 8 \alpha$-amyrine/ $\beta$-amyrone, 9) $\alpha$-amyrone.

good discrimination results were achieved, furthermore even B. bipinnata and B. stenophylla were correctly discriminated. $B$. penicillata is also well separated from the other species. Concerning $B$. excelsa and B. laxiflora they were grouped into the same area of hyperspace. Both species have a lower content of triterpenes compared to the other studied species, and this factor leads to a loss of sensibility in their discrimination using PCA with HPLC data (Figure 5).

When analyzing the loading plot (Figure 6), the molecules that exhibit the highest influence onto first component with positive values are peaks corresponding to triterpenes: lupenone, 3 -epi- $\alpha$-amyrin, lupenone, $\alpha$-amyrin/ $\beta$-amyrone. On the negative side with the highest impact B8 and B1 from the more polar fraction have a highest discrimination power.
On the negative part of first component B2, B5, A3 and A4, all volatile compounds have been shown to have a higher impact, together with 3-epi-lupeol from triterpenic fraction.

On the second component B3 and B5 have the higher impact in discrimination, they both seem to own the same information so for further analysis B5 may be taken out of the analysis as it exhibits a slightly lower impact on both components. Along with B3 and B5, $\alpha$-amyrone was found to have a high impact on second component. On the negative part of the second component A3, A4 and 3-epi-lupeol display the higher discrimination power.

Generally all triterpenes play a major role into discrimination except for lupeol which seems to have little impact on both components, and A1 which also exhibits a very 


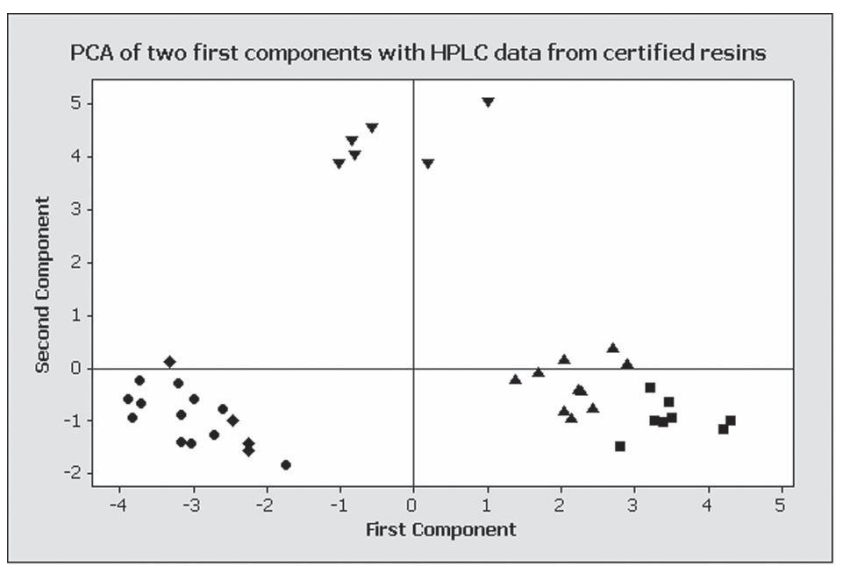

Figure 5: Distribution PCA of the resins samples from botanical certified origin with HPLC data. B. laxiflora, $\bullet$. excelsa, - B. stenophylla, $\boldsymbol{\Delta}$ B. bipinnata, $\boldsymbol{\nabla}$ B. penicillata. Figure 5 : Représentation ACP des résines certifiées botaniquement, en les données CLHP. B. laxiflora, $\bullet$ B. excelsa, $\mathbf{B}$ B. stenophylla, $\Delta$ B. bipinnata, $\boldsymbol{\nabla}$ B. penicillata.

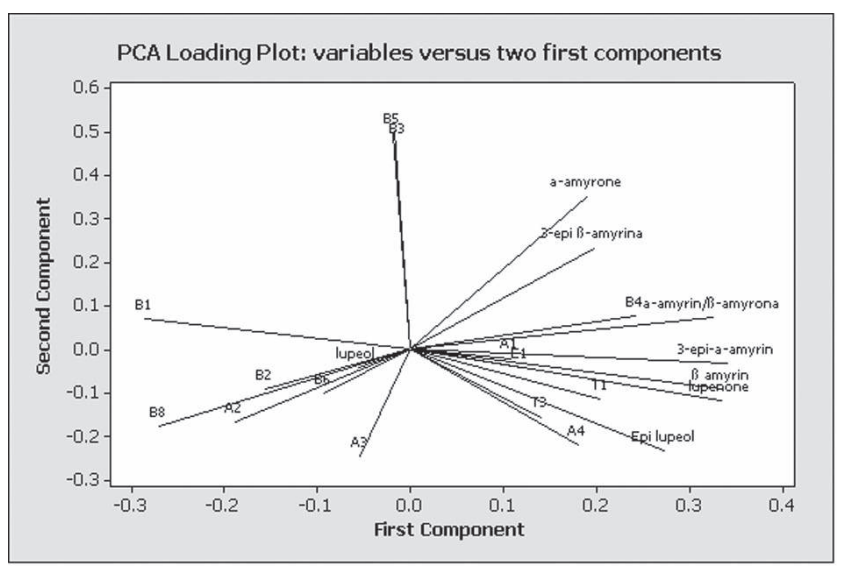

Figure 6: Loading plot for PCA analysis using HPLC data for botanical certified resins.

Figure 6: Graphique des variables en ACP utilisant les données HPLC des résines certifiées botaniquement.

limited influence into discrimination. This is reasonable if its ubiquity is considered.

\section{Linear Discriminant Analysis}

A classification model was built based on the same matrix used for PCA. LDA analysis was applied in order to find a predictive classification model, able to separate the five botanical species. Results for fitting analysis are shown on table 8 and in table 9 for validation matrix.
The confusion matrix (table 9) allowed a global recognition percentage of $95.0 \%$ while only one sample of $B$. excelsa and one from B. stenophylla samples were incorrectly classified in the validation procedure.

This can be considered as a consequence of dealing with classification from a sample of $B$. stenophylla, so that their probability to be correctly classified by this model is $87.5 \%$. On the other side B. bipinnata was always correctly classified. When looking at figure 5 with PCA classification, a greater dispersion of the individuals corresponding to $B$. stenophylla can be noticed, this fact leading to a greater possibility of misclassification of resin from this origin, when applying this model with the present data.

\section{HPLC coupled to PCA analysis for archaeological resins}

Data concerning the two archaeological samples from Templo Mayor were added into the matrix in an attempt to achieve the discrimination of their botanical origin. In this graph, it could only confirm the previous interpretation based only on chromatograms in which an origin between B. bipinnata and B. stenophylla is suggested (figure 4). Given the closeness of these two species in the hyperspace it was not possible to assess with certainty the botanical origin of the archaeological samples. This fact is also connected to the molecular changes that take place during ageing processes.

\section{Conclusion - Discussion}

The usefulness of HPLC-UV/Vis was undeniable concerning molecular profiling for differentiation between resins with different botanical origin. Currently the botanical distinction between B. stenophylla and B. bipinnata is unclear and the use of very techniques like HPLC-UV/Vis allows obtaining slight differences in the molecular composition of their resins. This closeness on molecular composition confirms the genetic closeness of these two species.

The advantage of coupling this liquid chromatographic technique with statistical methods such as PCA and LDA was to obtain a model able to discriminate botanical origin of fresh resins from species with similar molecular compositions such as B. bipinnata and B. stenophylla, which were difficult to differentiate using only chromatographic results. The performance of the mathematical model constructed with HPLC data in LDA shows a high resultwith 100\% recognition in the fitting matrix and a $95 \%$ of positive recognition in the cross validation matrix. 


\begin{tabular}{|c|c|c|c|c|c|}
\hline Put into group & B. bipinnata & B. excelsa & B. laxiflora & B. penicillata & B. stenophylla \\
\hline B. bipinnata & 10 & 0 & 0 & 0 & 0 \\
\hline B. excelsa & 0 & 4 & 0 & 0 & 0 \\
\hline B. laxiflora & 0 & 0 & 12 & 0 & 0 \\
\hline B. penicillata & 0 & 0 & 0 & 6 & 0 \\
\hline B. stenophylla & 0 & 0 & 0 & 0 & 8 \\
\hline Total N & 10 & 4 & 12 & 6 & 8 \\
\hline N correct & 10 & 4 & 12 & 6 & 8 \\
\hline Proportion & 1 & 1 & 1 & 1 & 1 \\
\hline \multicolumn{2}{|c|}{$N=40$} & \multicolumn{2}{|c|}{ N Correct $=40$} & \multicolumn{2}{|c|}{ Correct Proportion $=100 \%$} \\
\hline
\end{tabular}

Table 8: Fitting matrix of the LDA Rows represent the true class, and the columns the assigned class.

Tableau 8: Matrices d'ajustage en analyse linéaire discriminante, les lignes représentent la vraie classe d'appartenance, et les colonnes les classes attribuées.

\begin{tabular}{|c|c|c|c|c|c|}
\hline Put into group & B. bipinnata & B. excelsa & B. laxiflora & B. penicillata & B. stenophylla \\
\hline B. bipinnata & 10 & 0 & 0 & 0 & $1^{*}$ \\
\hline B. excelsa & 0 & 3 & 0 & 0 & 0 \\
\hline B. laxiflora & 0 & $1^{*}$ & 12 & 0 & 0 \\
\hline B. penicillata & 0 & 0 & 0 & 6 & 0 \\
\hline B. stenophylla & 0 & 0 & 0 & 0 & 7 \\
\hline Total N & 10 & 4 & 12 & 6 & 8 \\
\hline N correct & 10 & 3 & 12 & 6 & 7 \\
\hline Proportion & 1 & 0.75 & 1 & 1 & 0.875 \\
\hline \multicolumn{2}{|c|}{$N=40$} & \multicolumn{2}{|c|}{$\mathrm{N}$ Correct $=38$} & \multicolumn{2}{|c|}{ Correct Proportion = 95\% } \\
\hline
\end{tabular}

Table 9: Confusion matrix of LDA, rows represent the true class, and the columns the assigned class. Wrong assignments are marked with a * Tableau 9: Matrices de confusion en ADL, les lignes représentent la vraie classe et les colonnes la classe attribuée. Les attributionts incorrectes sont marqués d'une *.

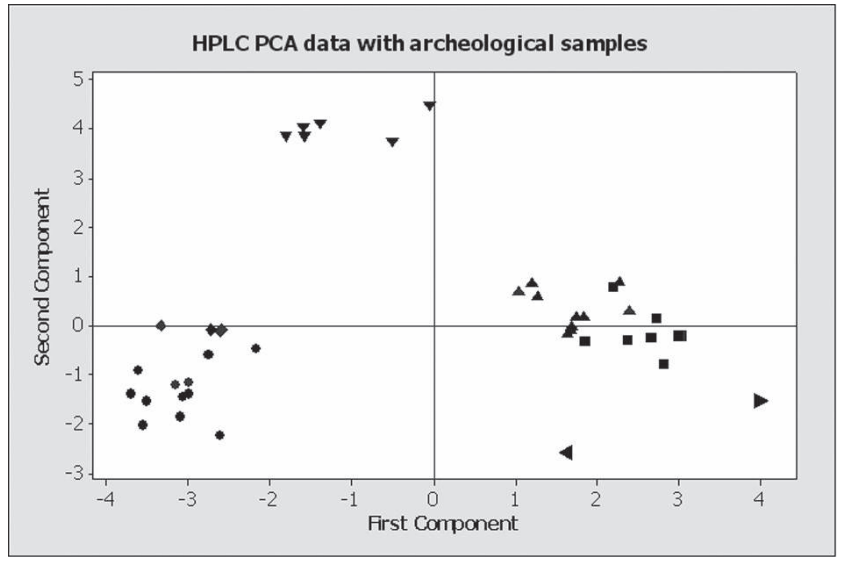

Figure 7. Distribution PCA of the resins samples from botanical certified origin including archaeological samples with HPLC data.
B. laxiflora B. penicillata, A B.

Figure 7. Représentation ACP des résines certifiées botaniquement et des échantillons archéologiques. B. laxiflora, B. excelsa, $\mathbf{B}$. stenophylla, $\boldsymbol{\Delta}$ B. bipinnata, $\boldsymbol{\nabla}$ B. penicillata, $A, \bigcirc B$.
Concerning ageing, liquid chromatography confirms that Bursera resins undergo significant changes over time: on the one hand a decrease of the polar compounds composition and on the other hand an oxidation and maybe a polymerization of the triterpenic fraction. These modifications can be assessed only partially by means of HPLC-UV/Vis, as it was presented on the chromatograms from archaeological samples and therefore a deepened study should imply the isolation of compounds $\mathrm{C} 1$ to $\mathrm{C} 3$ and its formal study by N.M.R. or MS-MS. Therefore there is a problem of loss concerning some compounds and the polymerization of others that lead to sometimes drastic changes in proportions between the compounds. It is also thought out to make an artificial ageing study of contemporary resins.

It is interesting to notice that some compounds are not always present in archaeological resins. Therefore an insight into the mechanism of their formation and maybe a correlation between ageing conditions and their presence should be established. 
In order to achieve a better botanical discrimination in aged samples, further studies need to be conducted about degradation processes, including the identification of nontriterpenic molecules and also molecules arisen from ageing.

In a second step, the establishment of correlations between products of degradation and stages of ageing could be established. Only a few molecules seem to be stable during natural ageing: A1 of the non-triterpenic fraction and all the triterpenic molecules except 3-epi- $\beta$-amyrin, which nevertheless exhibited a tendency to proportion change.

Molecular profile of both archaeological resins is quite close despite a slight difference in conservation state. Generally speaking, burial environment contributes to a extent to the good preservation of these materials based on molecular profile for both samples analyzed in this work, even though they were collected from different offerings (offerings 120 and 126). The analysis results on archaeological samples suggest that they could be resins of either $B$. bipinnata or B. stenophylla species. Pollen of B. bipinnata has been founded by paleobotanists, in archaeological context in the site of Templo Mayor (Montufar, 2007). However, $B$. bipinnata is a species with a wide geographical presence and sometimes it produces hybrids with other members of the Bullockia botanical section.

On the historical part, the results of these experiments confirmed the accuracy of information contained in chronicles from 16th century from B. Sahagún about the numerous uses that Aztecs and original people from Mesoamerica gave to copal. This research also yielded important information for archaeologist that was previously unavailable: firstly this work confirms, on the molecular level, that materials found at Templo Mayor offerings are natural solid resins, and that one botanical origin of copal among the great variety of over 80 possible species of Bursera available at Aztec empire, seems to be preferred by the priests.

\section{Acknowledgments}

The authors are grateful to Dr. Leonardo López, Dr. Maria Barajas and Dr. Aurora. Montúfar, who provided the archaeological resins that were examined. They are also grateful to the National Council of Science and Technology of Mexico (CONACYT) for the Doctoral grant for Paola Lucero-Gomez.

\section{References}

Alonso A., Guevara M., Escalante M.F., Garay M., González A., Hans M., Miramontes A.B., Sanromán A., 2008. Informe de las actividades de conservación y restauración de la colección de bienes arqueológicos del Proyecto Templo MayorSéptima Temporada. Julio-Diciembre 2008. Coordinación Nacional de Conservación del Patrimonio Cultural, ENSR y M Manuel Catillo Negrete, Museo de Templo Mayor, INAH, México. (Unpublished Material).

Armanino C., Casolino M.-C., Casale M., Forina M., 2008. Modelling aroma of 3 italian red wines by head space-mass spectrometry and potential functions. Analytica chimica acta, 614: 134-142.

Barreto C., 2009. Minería de datos aplicada a la mejora de procesos de extrusión de elastómeros. Ph. D. thesis. Polytechnic University of Valencia, Spain.

Becerra J., Venable L., Evans P.-H., Bowers W., 2001. Nuclear ribosomal DNA phylogeny and its implications for evolutionary trends in mexican Bursera (Burceraceae). American Zoology, 41: 865-986.

Bonaduce I., Brecoulaki H., Colombini M.P., Lluveras A., Restivo V., Ribechini E., 2007. GC-MS characterization of plant gums in samples from painted works of art. Journal of Chromatography A, 1175: 275-282.

Bucio L., Belío-Reyes I. A., Rodríguez J. A., Orta M. N., Arenas-Alatorre J., Magaña C., Velázquez R., 2006. Incrustation of precious stones in dental apatite. Zeitschrift für Kristallographie Supplement, 23: 569-574.

Büchele B., Zugmaier W., Simmet T., 2003. Analysis of pentacyclic triterpenic acids from frankincense gum resins and related phytopharmaceuticals by high-performance liquid chromatography. Identification of lupeolic acid, a novel pentacyclic triterpene. Journal of Chromatography B, 791: 21-30.

Carrasco D., 1999. City of Sacrifice. The Aztec empire and the role of violence in civilization. Boston, Beacon Press, United States.

Casale M., Zunin P., Cosulich M.-E., Pistarino E., Perego P., LANTERi S., 2010 a. Characterisation of table olive cultivar by NIR spectroscopy. Food chemistry, 122: 1261-1265.

Casale M., Sinelli N., Oliveri P., Di Egidio V., Lanteri S., 2010 b. Chemometrical strategies for feature selection and data compression applied to NIR and MIR spectra of extra virgin olive oils for cultivar identification. Talanta, 80: 18321837.

Colombini M.P., Modugno F., Giacomelli A. 1999. Two procedures for suppressing interference from inorganic pigments in the analysis by gas chromatography-mass spectrometry of proteinaceous binders in paintings. Journal of chromatography A, 846: 101-111. 
Colombini M.-P., Modugno F., Giannarelli S., Fuoco R., Matteini M., 2000. GC-MS characterization of paint varnishes. Microchemical Journal, 67: 385-396.

Colombini M.P., Ceccarini A., Carmignani, A. 2002. Ion chromatography characterization of polysaccharides in ancient wall paintings. Journal of Chromatography A, 968: 79-88.

Cosio M., Ballabio D., Benedetti S., Gigliotti C., 2006. Geographical origin and authentication of extra virgin olive oils by an electronic nose in combination with artificial neural networks. Food Chemistry, 101: 485-491.

Culioli G., Mathe C., Archier P., Vieillescazes C., 2003 A lupane triterpene from frankincense (Boswellia sp., Burseraceae). Phytochemistry, 62: 537-541.

De la Cruz-Cañizares J.M., Doménech-Carbó J., GimenoAdelantado J.V., Mateo- Castro R., Bosch-Reig F., 2005. Study of Burceraceae resins used in binding media and varnishes from artworks by gas chromatography-mass spectrometry and pyrolysis-gas chromatography-mass spectrometry. Journal of Chromatography A. 1093: 177-194.

Doménech-Carbó M., 2008. Study of ageing of ketone resins used as picture varnishes by FTIR spectroscopy, UV-Vis spectrophotometry, atomic force microscopy and scanning electron microscopy X-ray microanalysis. Analytica Chimica Acta, 621: 109-139.

García A., 2002. Modelización por técnicas no paramétricas del proceso de mezclas de gomas para extrusión. Doctoral thesis. University of La Rioja. Spain

Gautier G., Colombini M., 2007. GC-MS identification of proteins in wall painting samples: A fast clean-up procedure to remove copper-based pigment interferences. Talanta, 73: 95-102.

Hernández-Vázquez L., Mangas S., Palazon J., NavarroOcAÑA A., 2010. Valuable medicinal plants and resins: commercial phytochemicals with bioactive properties. Industrial Crops and Products 31: 476-480.

Frisvad J., Andersen B., Thrane U., 2008. The use of secondary metabolite profiling in chemotaxonomy of filamentous fungi. Mycological Research 112: 231- 240.

LACHLAN G., 1992. Discriminant analysis and statistical pattern recognition. Wiley. New York, USA.

Langenheim J.H., 2003. Plant resin, Chemistry, evolution, ecology, ethnobotany. Timber press, Cambridge, United Kingdom.

López-Luján L., Chavez X., 2010. Al pie del Templo Mayor: excavaciones en busca de los soberanos Mexicas. In Moctezuma II: tiempo y destino de un gobernante. López Luján L. and McEwan C. (dir.), INAH, Mexico.

López-Luján L., 1993. Las ofrendas del Templo Mayor de Tenochtiltlan. Instituto Nacional de Antropología e Historia, Mexico.
Lucero-Gómez P., 2012. Chemical Analyses of resinous materials employed in artistic field in Pre-Hispanic Mexico. Application to Aztec and Maya archaeological samples. PhD thesis, University of Avignon. France.

Lucero-Gómez P., Mathe C., Vieillescazes C., Bucio L., Belio I., Vega R., 2014. Analysis of Mexican reference standards for Bursera spp. Resins by Gas Chromatography-Mass Spectrometry and application to archaeological objects. Journal of Archaeological Science, 41: 679-690.

Magaloni D., Newman R., Baños L., Falcón T., 1993. Los pintores de Bonampak. In, Eighth Palenque Round Table. Martha J. Macri and McHarque Jan (dir.). Pre-Columbian Art Research Institute, San Francisco, United States.

Magar V., Menar P., 1995. Investigación para la interpretación y la conservación de un disco de mosaico de turquesa. Master thesis. National Institute of Conservation, Restauration and Museography Manuel del Castillo Negrete, Mexico.

Mathe C., Culioli G., Archier P., Vieillescazes, C. 2004. High-performance liquid chromatographic analysis of triterpenoids in commercial frankincense. Chromatographia. 60: 493-499.

Matos-Moctezuma E., López-Lujan L., 2007. Tlaltecuhtli de la Casa de las Ajaracas y el Rey Ahuizotl. Arqueología Mexicana, 83: 23-29.

Matos-Moctezuma E., 2011. De conservaciones y restauraciones, Arqueología Mexicana, 108: 24-27.

Mills J., White R., 1977. Natural resins of art and archaeology: their sources, chemistry, and identification. Studies in Conservation, 22: 12-31.

Modugno F., Ribechini E., Colombini M.P., 2006. Raw and archaeological materials. Journal of Chromatography A, 1134: 298-304.

Montúfar A., 2007. Los Copales Mexicanos y la resina sagrada del Templo Mayor de Tenochtitlan. Instituto Nacional De Antropología e Historia Mexico city, Mexico.

Navarrete-Linares F., 1998. La migración de los Mexicas. Consejo Nacional para la Cultura y las Artes, Mexico.

Orta-Amaro M., 2007. Copal: Microestructura, composición y algunas propiedades relevantes. Thesis of Engineering in chemistry. National Polytechnic Institute of Mexico. Mexico.

Rezzi S., Bighelli A., Castola V., Casanova J., 2005. Composition and chemical variability of the oleoresin of Pinus nigra ssp. laricio from Corsica. Industrial Crops and Products, 21: 71-79.

Rzendowski J., Lemos R.M., Caderon de Rzendowski G., 2005. Inventario del conocimiento taxonómico de la diversidad y del endemismo de las especies mexicanas de Bursera (Burseraceae). Acta Botanica Mexicana, 70: 85-111.

Sahagún F.B., 2006. Historia general de las cosas de Nueva España. Colecc: Sepan cuantos 300. Ed.Porrua. Mexico city, Mexico. 
Stacey R.J., Cartwright R., 2006. Chemical Characterization of Ancient Mesoamerican Copal Resins: Preliminary Results. Archeaometry, 48: 323-340.

Terradez M., Principal component analysis. University Oberta de Cataluña. [http://www.uoc.edu/in3/emath/docs/Componentes_ principales]. Consulted on June 2013.

Tapp H., Defernez M., Kemsley E.K., 2003. FTIR spectroscopy and Multivariate Analysis can distinguish the geographical origin of extra virgin olive oils. Journal of Agricultural Food Chemistry, 51: 6110-6115.

Vandenabeele P., Grimaldi D.M, Edwards H.G., Moens L., 2003. Raman spectroscopy of different types of Mexican copal resins. Spectrochimica Acta A ,59: 2221-2229.
Vandenabeele P., Ortega-Avilès M., Castilleros D.T., Moens L., 2007. Raman spectroscopic analysis of Mexican natural artists' materials. Spectrochimica Acta A, 68:1085-1088.

Victoria-Lona N. 2004. Objects made of copal resin: a radiological analysis. Arqueología Mexicana, 111: 64-71.

Vieillescazes C., Coen S., Larice J.L., 1996. Ancient resinous substances characterisation : an approach by Principal Component Analysis. Analytica Chimica Acta, 317: 65-73.

Whistler R.-L., 1993. Exudate gums. In: Industrial gums: Polyssacharides and their derivatives, ed.3, eds. R.L. Whistler and J.N. Bemiller. Academic press, New York. 